\title{
PEMBINAAN MASYARAKAT MULTIKULTURAL DALAM MENINGKATKAN KERUKUNAAN ANTAR UMAT BERAGAMA
}

\author{
Fety Novianty \\ Program Studi PPKN Fakultas Ilmu Pendidikan dan Pengetahuan Sosial IKIP PGRI Pontianak \\ Jalan Ampera Nomor 88 Pontianak, Telepon (0561) 748219 Fax. (0561) 6589855 - 78116 \\ email: putrikhanza96@yahoo.co.id
}

\begin{abstract}
Abstrak
Tulisan ini bertujuan untuk mendeskripsikan mengenai pembinaan masyarakat multikultural dalam meningkatkan kerukunan antar umat beragama. Perlunya dilakukan pembinaan masyarakat multikultural, karena adanya perbedaan agama, budaya, suku, bahasa, adat istiadat dan kepentingan sosial lainnya. Karena kekayaan budaya dan kemajemukan yang dimiliki bangsa Indonesia ini, sesungguhnya bisa menjadi potensi integrasi, sebaliknya manakala perbedaan itu dikelola kurang baik, maka hal itu akan menjadi potensi disintegrasi bangsa. Pembinaan masyarkat multicultural disini, jika dihubungkan dengan kondisi bangsa Indonesia saat ini kiranya menjadi sangat jelas bahwa multikulturalisme perlu dikembangkan di Indonesia. Dengan cara itu kita dapat memaknai "Bhinneka Tunggal Ika" secara tepat dan benar, seimbang dan proporsional. Melalui kebijakan ini pula kita dapat menerapkan "Persatuan Indonesia" dengan mengembangkan semangat nasionalisme sebagaimana diharapkan. Untuk itu penerapan dan pembinaan multikulturalisme di Indonesia perlu diberi cirri khusus dalam konteks untuk meningkatkan kerukunan antar umat beragama.
\end{abstract}

Kata Kunci: Masyarakat Multikultural, Kerukunan Antar Umat Beragama

\begin{abstract}
This paper aims to describe the formation of multicultural societies in increasing harmony among religious communities. The need to foster multicultural societies, because of differences in religion, culture, ethnicity, language, customs and other social interests. Because of the cultural richness and diversity possessed by the Indonesian people, this can actually be a potential for integration, on the contrary if the differences are not well managed, it will become a potential for national disintegration. The development of multicultural society here, if it is related to the current condition of the Indonesian nation, it would be very clear that multiculturalism needs to be developed in Indonesia. That way we can interpret "Unity in Diversity" precisely and correctly, balanced and proportional. Through this policy we can also implement "Indonesian Unity" by developing the spirit of nationalism as expected. For this reason, the application and promotion of multiculturalism in Indonesia needs to be given special characteristics in the context of increasing harmony among religious communities.
\end{abstract}

Keywords: Multicultural Communities, Interfaith Harmony

\section{PENDAHULUAN}

Munculnya wacana Multikultural merupakan reaksi terhadap adanya pluralitas yang begitu kompleks di dalam masyarakat, yang didalamnya tidak hanya pengakuan yang dibutuhkan, tetapi juga kesadaran budaya yang inklusif dan transformatif. Suparlan (2005:98) menyatakan Multikulturalisme dikembangkan dari konsep pluralisme budaya (culture pluralism) dengan menekankan kesederajatan kebudayaan yang ada dalam sebuah masyarakat.

Prinsip-prinsip dasar Multikultural mengakui dan menghargai keberagaman kelompok masyarakat seperti etnik, ras, budaya, gender, strata sosial, agama, perbedaan kepentingan, keinginan, visi, keyakinan dan tradisi yang akan sangat membantu bagi terwujudnya perubahan perilaku yang kondusif dan sangat menjanjikan di tengah kehidupan masyarakat dan bangsa yang majemuk. Dengan demikian pendekatan multikultural tidak sesungguhnya berlandaskan 
pada kepemilikan yang mengisyaratkan pada memiliki atau dimiliki budaya tertentu tetapi berlandaskan pada kesadaran untuk menghargai dan menghormati.

Dari pengertian multikulturalisme sebagaimana disebutkan diatas, bila dihubungkan dengan kondisi Indonesia saat ini, menjadi sangat jelas bahwa multikulturalisme dapat dikembangkan di Indonesia, karena dengan gagasan ini kita dapat memaknai keragaman dari sisi etnis, agama, golongan sosial ekonomi maupun orientasi politik. Konsep ini dapat memperkaya konsep kerukunan umat beragama yang dikembangkan secara nasional di Negara kita.

Keberagaman masyarakat yang multikultural sangat potensial untuk terjadinya konflik antar etnik atau antar umat beragama. Oleh karena setiap kelompok etnik senantiasa tetap mempertahankan identitas etnik dan kulturnya. Belum lagi menyangkut persoalan kurang mampunya masing-masing etnik dalam membangun perbedaan identitas dan kultur sebagai realitas sosial yang disikapi secara positif.

Kalimantan Barat merupakan salah satu daerah Indonesia yang berpenduduk sangat heterogen yang memiliki intensitas konflik yang tinngi. Pemerintah propinsi Kalimantan Barat (2005: 2) menyebutkan sejak tahun 1950 sampai dengan tahun 1999 telah terjadi sepuluh kali konflik. Konflik terbesar terjadi pada tahun 1997 di Sanggau Ledo dan tahun 1999 terjadi di Sambas. Kedua konflik ini merupakan salah satu bukti pengalaman sejarah kelam dalam hubungan sosial etnis antar masyarakat Kalimantan Barat. Namun, konflik etnis yang terjadi bukan tidak mungkin dapat menimbulkan konflik antar umat beragama. Bahkan mungkin bisa dikatakan di dalam konflik etnik sebetulnya juga terjadi konflik agama. Karena antara etnik dan agama keduanya sulit dipisahkan, seperti dua sisi mata uang. Bagi etnik tertentu seperti, melayu itu lebih diidentikkan ke Islam, sedangkan Dayak lebih diidentikkan ke Kristen. Tapi apabila orang Dayak masuk islam dengan serta merta mereka diakui sebagai orang melayu.

Mengkaji soal kerukunan antar umat beragama berarti ada problem moralitas individu atau masyarakat yang dikaji kembali secara kritis. Moralitas berkenaan dengan tingkah laku yang konkret. Terutama adanya sikap tidak toleransi, menghargai dan menghormati sedangkan multikultural bekerja dalam level teori.

Jadi, berdasarkan argumen diatas, bahwa ketidak mampuan memahami perbedaan dalam etnik atau agama diluar dirinya yang dapat berakibat terjadinya konflik sehingga tidak terciptanya kerukunan antar umat beragama serta asumsi yang harus diuji kebenarannya tadi, maka penulis merasa tertarik untuk meneliti persoalan ini. Atas pemikiran tersebut maka penulis tertarik untuk menganalisis mengenai Pembinaan Masyarakat Multikultural dalam Meningkatkan Kerukunan Antar Umat Beragama. 


\section{METODE PENELITIAN}

Penulisan artikel ini menggunakan metode kajian pustaka dan studi deskriptif. Penulis menggunakan kajian pustaka dengan maksud untuk mengeksplorasi tulisan ini karena banyak menggunakan referensi yang berkaitan dengan tema artikel ini. Referensi tersebut berupa literature buku tentang masyarakat multikultural dan kerukunan antar umat beragama, artikel/ jurnal, dengan kaidah metodologis berupa keterkaitan interpretasi, induksi dan deduksi.

\section{HASIL DAN PEMBAHASAN}

\section{Konsep Masyarakat Multikultural}

Istilah Multikulturalisme ini muncul sekitar tahun 1970-an. Pertama kali berkembang di Kanada dan Australia kemudian di Amerika Serikat, Inggris dan Jerman yaitu sebagai gerakan yang mengusung dan keberpihakan serta penghargaan terhadap multikultural sebagai realitas budaya. Tujuan yang hendak dicapai pluralisme adalah mewujudkan masyarakat yang dialogis, toleran, dan dinamis. Kendatipun demikian, pluralism tidak menyentuh domain kelompok etnis, adat, dan kelompok minoritas lainnya. Di sini multukulturalisme hadir sebagai alternatif untuk menciptakan keharmonisan dan memberikan perlindungan terhadap kelompok minoritas etnik serta adat.

Elemen-elemen multikulturalisme menurut Blum (2001: 19) mencakup tiga sub nilai berikut : menegaskan identitas cultural seseorang, mempelajari dan menilai warisan budaya seseorang : menghormati dan berkeinginan untuk memahami dan belajar tentang etnik/ kebudayaan-kebudayaan selain kebudayaannya; dan menilai serta merasa senang dengan perbedaan kebudayaan itu sendiri, yaitu memandang keberadaan dari kelompok-kelompok budaya yang berbeda dalam masyarakat seseorang sebagai kebaikan yang positif untuk dihargai dan dipelihara. Pendapat Blum tersebut lebih jelasnya diuraikan dibawah ini.

Pertama pengertian suatu "pemahaman identitas cultural orang lain" tidak diartikan ataupun menegaskan bahwa semua aspek kebudayaan itu seluruhnya "baik ", seperti yang banyak dikhawatirkan oleh beberapa kritikus multikulturalisme. Suatu pemahaman identitas cultural orang lain dalam hal ini tidak menghalangi kritik berdasarkan standar-standar dari kebudayaannya yang mungkin dilanggar oleh kebiasaan khusus dalam kebudayaan tersebut, maupun berdasarkan norma-norma eksternal bagi kebudayaan itu (Schramm, 2001: 7; Spradeley, 1997; 13-15).

Kedua, multikulturalisme itu "menghormati keebudayaan-kebudayaan orang lain" merupakan kelanjutan yang penting bagi focus kegiatan pertama. Tilaar, (2004; 94) mengemukakan multikulturalisme menuntut kehidupan bersama yang penuh toleransi, tetapi 
saling pengertian antar budaya, antar bangsa dalam membina suatu dunia yang baru. Pemahaman tersebut dimaksudkan tidak sekedar sesuatu yang bisa ditolerir apalagi dibenarkan, melainkan diperlukan untuk berperan serta dalam memberikan dukungan, alasan-alasan, pengakuan, penghargaan, penilaian, penguatan, dan empati dalam kebersamaan hidup sebagai bagian bangsa secara integral.

Dari pengertian multikulturalisme sebagaimana dikemukakan diatas, jika dihubungkan dengan kondisi bangsa Indonesia saat ini kiranya menjadi sangat jelas bahwa multikulturalisme perlu dikembangkan di Indonesia. Dengan cara itu kita dapat memaknai "Bhinneka Tunggal Ika" secara tepat dan benar, seimbang dan proporsional. Melalui kebijakan ini pula kita dapat menerapkan "Persatuan Indonesia" dengan mengembangkan semangat nasionalisme sebagaimana diharapkan. Untuk itu penerapan dan pembinaan multikulturalisme di Indonesia perlu diberi cirri khusus dalam konteks untuk meningkatkan kerukunan antar umat beragama.

\section{Kontribusi Kerukunan Antarumat Beragama}

\section{Ruang Lingkup Kerukunan Antarumat Bragama}

Kerukunan berasal dari kata rukun berarti baik dan damai,tidak bertengkar. Kerukunan merupakan suatu kemauan untuk hidup bersama berdampingan secara damai dan tertib. ”Dengan demikian dalam masyarakat tercipta suasana kedamaian, ketertiban dan ketentraman, tanpa ada pertikaian dan pertengkaran”. (Suradi Abu Bakar, 2000: 16).

Membahas mengenai kerukunan umat beragama beberapa waktu ini bangsa Indonesia sedang mengalami ujian yang sangat berat dalam berbagai persoalan bangsa, yaitu sering terjadinya konflik-konflik internal umat beragama maupun atarumat beragama maupun antarumat beragama dengan pemerintah. Sebagaimana konflik yang kita alami konflik diberbagai daerah wilayah Indonesia.

Pengembangan kerukunan antarumat beragama dalam pengembangan kerukunan antarumat beragama sangat diperlukan. Dalam Peraturan bersama Menteri Agama dan Menteri Dalam Negeri No.9 Tahun 2006 Tanggal 21 Maret 2006 didefinisikan bahwa :

Kerukunan Umat Beragama adalah keadaan hubungan sesama umat beragama yang dilandasi toleransi, saling pengertian, saling menghormati, menghargai kesetaraan dalam pengamalan ajaran agamanya dan kerjasama dalam kehidupan bermasyarakat, berbangsa dan bernegara di dalam Negara Kesatuan Republik Indonesia berdasarkan Pancasila dan Undang-Undang Dasar tahun 1945.

Sebenarnya ada faktor-faktor yang dapat mempengaruhi kerukunan dalam kehidupan bermasyarakat, berbangsa dan bernegara antara lain :

1. Macetnya komunikasi antara pemerintah dengan rakyat baik dalam hal kekuasaan politik) meupun sosial ekonomi. 
2. Kepentingan yang beranekaragam dan masih munculnya ikatan-ikatan primordial yang mengemuka (agama, suku dan budaya).

3. Ketimpangan dan kesenjangan atas kemampuan sosial dan ekonomi.

4. Pengaruh ekonomi dan poitik global sebagai imbas dari kepentingan internasional terhadap Indonesia, dan

5. Budaya paternalistic dan budaya feudal yang masih mempengaruhi ola kehidupan masyarakat.

Agar kerukunan hidup umat beragama harus terwujudkan maka harus dikembangkan suasana kehidupan yang harmonis, dan hal itu hanya akan terwujud jika setiap orang memiliki sikap dan perilaku sebagai manusia yang beriman dan bertakwa. Perwujudan sikap dan perilaku manusia yang bertakwa dan beriman kepada Tuhan ditujukan dengan kepatuhan dan ketaatan dalam menjalankan perintahya; yaitu menjalankan ibadah, selalu berbuat kebaikan, serta membantu orang yang kesusahan, selalu jujur serta menjunjung tinggi kebenaran dan menjauhi segala larangan Tuhan. (Suradi Abu Bakar dkk, 200:22).

Berdasarkan pernyataan diatas maka kerukunan hidup beragama bukanlah mengsinkretkan ajaran ajaran agama dalaam arti mencampur adukkan ajaran agama, tetapi kerukunan sesama warga Negara yang berbeda agama, bersatu untuk saling membnatu, setidak-tidaknya tidak saling menganggu.

\section{Kerukukan kehidupan antarumat beragama di Indonesia}

Agar manusi dapat mencapai tujuannya, diperlukan situasi dan kondisi yang kondusif yang cukup mendukung. Kerukunan dalam kehidupan masyarakat dapat dapat diuraikan dalam tri kerukunan yaitu:

a. Kerukunan umat beragama (intra) seagama

b. Kerukunan antarumat beragama

c. Kerukunan umat beragama dengan pemerintahnya, sebagai penyelenggara tata laksana kenegaraan. (Suradi Abu Bakar dkk, 2000: 2).

Terwujudnya Konsep tri kerukunan tersebut tentu harus diusahakan oleh subjek dalam kehidupan masyarakat, dengan demikian setiap umat beragama haruslah merasa berkewajiban memiliki dan mengusahakan kerukunan hidup dengan perwujudan perbuatan, yang akan dijabarkan di pembahasan selanjutnya.

a. Kerukunan Intern Umat Beragama

Kerukunan intern umat beragama berarti kerukunan antara pemeluk salah satu agama salah satu kepercayaan (Djoko Priyanto, 2005). Kerukunan intern umat beragama sebetulnya sudah lama dikembangkan oleh bangsa Indonesia melalui kerja sama berbagai komponen masyarakat yang terkait. Hal ini terbukti dengan adanya berbagai kelompok keagamaan yang tersebar luas diseluruh nusantara, masing-masing saling mempererat tali silaturahmi dan 
saling menjaga satu dengan yang lainnya. Bahkan ada organisasi-organisasi keagamaan yang usianya lebih tua dari kemerdekaan bangsa Indonesia.

Jika melihat kasus kerukunan intern umat beragama ini adalah seperti kasus Aceh adalah kasus yang berat, penanganannya harus penuh hati-hati dan penuh kasih. Semua yang bertikai harus saling menahan diri untuk saling merusak, menyakiti, ataupun membunuh dan hal tersebut berusaha direalisasikan melalui pemberlakuan hukum islam yang tetap dijalankan. Serta pengiriman beberapaa ulama untuk berdialog dengan masyarakat, dan pemberian bantuan moril dan materiil (Said Agil, 2003: 2).

Selain lembaga informal yang paling utama menurut Muhammad M. Basyuni (Menteri Agama RI) pembinaan kerukunan intern umat beragama harus dibantu dikembangkan bersama-sama oleh para pemimpin majelis-majelis agama. Seperti MUI, PGI, KWI, PHDI, WALUBI, MATAKIN dengan melakukan pendekatan dan dialog dengan cara intensif ke berbagai daerah di Indonesia, sehingga tercipta suasana rukun, damai dan tenteram (2006:30). Keuntungan pembinaan kerukunan intern umat beragama melalui lembaga formal adalah terwujudnya " langkah strategis dalam pengembangan kerukunan intern umat beragama".

b. Kerukunan Antar Umat Beragama

Kerukunan antar umat beragama dewasa ini sudah menunjukkan adanya titik-titik harmonisasi antara orang-orang yang terlibat didalamnya. Sehingga diperlukan adanya pembinaan lebih lanjut dan diarahkan pada pendekatan humanis cultural. Oleh karena itu peranan tokoh-tokoh agama sangat strategis dalam membina umat beragama terutama dalam peningkatan pengetahuan dan wawasan keagamaannya, sebab yang mempunyai kecenderungan kurang rukun pada umumnya adalah :

Kelompok umat beragama yang masih sangat terbatas pemahaman dan aplikasi nilai-nilai keagamaannya. Jika pemuka-pemuka agama tidak bisa memahami dan meneladankan atas perbedaan dan persamaan antar agama kepada masyarakat, maka akan timbul kasus-kasus yang mengakibatkan terjadinya kerawanan, antara lain " konflik intern umat beragama maupun antar umat beragama dengan pemerintah", yang dimanfaatkan oleh golongan ekstrim dalam bentuk adu domba/ memecah belah (Ahmad Zubair, 2003:11).

Kehidupan umat beragama yang dilandasi prinsip menghormati kebebasan memeluk agama dan beribadah menurut kepercayaan itu, akan terasa indah. Keindahan umat beragama yang dilandasi prinsip tersebut tampak dalam :

1. Terbinanya suasana tenang, damai, tertib dan menjunjung tinggi toleransi

2. Terbinanya kerjasama antar umat beragama dalam mencapai kebahagiaan hidup

3. Terbinanya sikap keterbukaan antar umat beragama

4. Terbinanya kerukunan hidup bermasyarakat. (Suradi Abubakar dkk, 2000:22). 
c. Kerukunan Antar Umat Beragama dengan Pemerintah.

Pemerintah sebagai pelindung dan penyedia bagi masyarakatnya memiliki fungsi yang sangat strategis karena ia memiliki lembaga formal yang dapat mengatur keseluruhan kehidupan beragama secara lebih tertib. Oleh karenanya peran dan fungsi lemabaga harus optimal. Peranan penting agama dalam membina kerukunan antar umat beragama dikembangkan dengan peningkatan peran serta fungsi lembaga-lembaga keagamaan. Fungsi dan peranan lembaga agama itu antara lain :

1. Memberikan fatwa atas permasalahan yang menyangkut ketentuan agama

2. Membina peningkatan kualitas iman dan takwa umat beragama, serta ajaran agama yang benar

3. Membina kerukunan umat beragama dan

4. Memberikan pertimbangan dan usulan bagi pemerintah mengenai permasalahan keagamaan. (Abdul Fatah, 2003:7)

Kerukunan antar umat beragama dengan pemerintah diwujudkan dalam berbagai bentuk mulai dari konsolidasi intern umat beragama, dan kerja sama antar umat beragama. Terutama semuanya itu bisa atau dapaat difasilitasi Negara atau pemerintah yang memiliki sarana dan jaringan yang lebih luas sehingga sebuah kerukunan yang ingin diciptakan merupakan kerukunan umat beragama yang simultan dan terkoordinir dengan baik. Harapannya dapat memuaskan semua kalangan dan terciptanya ketertiban serta kedamaian kehidupan berbangsa dan bernegara.

\section{Hambatan dalam Masyarakat Multikultural}

Dalam masyarakat multicultural, konflik bisa saja terjadi berkaitan dengan sulitnya membangun sebuah kebijakan yang dapat memenuhi semua aspirasi dan kepentingan yang cenderung semakin kompleks sehingga dapat memunculkan suatu kondisi yang tidak memaksa dan mempengaruhi rasa keadilan. (Suwarma 2008:116).

Konflik merupakan keadaan yang tidak terpisahkan dari keberadaan masyarakat majemuk. Amri Marzali (2003:15-25) mengatakan perbedaan etnis dan sosio ekonomi mempengaruhi dalam konflik. Mempertahankan identitas dan kurangnya kesadaran toleransi antaragama juga memberikan andil terjadinya konflik. (Budianti 2003:121).

Mengkaji kembali apa yang menjadi norma sosial-kultural sesungguhnya yang membentuk struktur sosial. Dapat dikatakan bahwa sistem sosial budaya Indonesia, terbentuk melalui proses fungsional dan struktural yang diwarnai dengan konflik vertical dan horizontal. Proses penyeimbangan dari berbagai factor tersebut menciptakan suatu norma yang disepakati dan dijalankan bersama-sama dengan sungguh-sungguh. Maka norma merupakan sebuah tata nilai yang tidak hanya tumbuh melalui kesepakatan- kesepakatan bersama, melainkan dapat 
diwujudkan melalui kebijakan yang dikeluarkan oleh pemerintah untuk menyelesaikan konflik yang terjadi di masyarakat.

Namun demikian perlu diperhatikan potensi konflik yang terjadi antara satu sama lain sebagai akibat benturan fungsional yang terjadi antar individu. Secara laten konflik sangat potensial terjadi pada setiap sistem budaya. Karena pemahaman terhadap adanya penyakit budaya tersebut merupakan kunci utama dalam resolusi dan manajemen konflik. Negara membutuhkan solusi yang memuaskan dalam menghadapi ancaman konflik dan separatisme di daerah- daerah yang disebabkan oleh tumbuh berkembangnya penyakit budaya seperti prasangka, streotipe, etnosentrisme, dan diskriminasi.

\section{a. Prasangka Sosial}

Prasangka secara etimologis berasal dari penggabungan dua kata yang berasal dari kata prae yang berarti "sebelum" dengan kata judicium yang berarti "penilaian akhir". Dari penggabungan kedua kata ini, kata prejudis dapat diartikan menjadi "sebuah penilaian akhir yang tidak dilandasi dengan bukti-bukti terlebih dahulu”. Sedangkan secara sosiologis, prasangka adalah sebuah opini, sikap, kepercayaan, dan perasaan yang negatif serta tidak fair terhadap seseorang atau kelompok masyarakat lain 9etnis, kewarganegaraan, agama, ras, jenis kelamin, partai politik, keluarga, organisasi tertentu, kelas sosial dan lain-lain.

Salah satu bentuk prasangka (prejudice), prasangka adalah sikap negative terhadap kelompok tertentu atau seseorang, semata-mata karena keanggotaannya dalam kelompok tertentu. Sarlito Wirawan (2003:267) menyatakan bahwa prasangka timbul karena penilaian yang tidak berdasar dan pengambilan sikap sebelum menilai dengan cermat, sehingga terjadi penyimpangan pandangan (bias) dari kenyataan yang sesunnguhnya.

Elliot Arronson (1992:312-321) menjelaskan empat kategori penyebab prasangka yaitu:

1. Adanya kompetisi ekonomi dan politik dapat menyebabkan prasangka terhadap orang atau kelompok masyarakat lain.

2. Membuat serangan terhadap lawan dalam bentuk yang tidak nyata sehingga si penyerang tidak diketahui atau menyerang kelompok lain dengan cara memfitnah.

3. Kebutuhan personal. Kepentingan dan kebutuhan personal seseorang maupun kelompok dapat menyebabkan prasangka.

4. Penyesuaian terhadap norma-norma yang ada disekitarnya.

Berdasarkan beberapa pengertian para ahli diatas, dapat disimpulkan bahwa prasangka mengandung sikap, pengertian, keyakinan, dan bukan tindakan. Jadi prasangka tetap ada pikiran, sedangkan diskriminasi mengarah ke tindakan sistematis. Kalau prasangka berubah menjadi kehidupan nyata, maka prasangka sudah berubah menjadi diskriminasi yaitu tindakan menyingkirkan status dan peranan seseorang dari hubungan, pergaulan, dan 
komunikasi antar manusia. Secara umum kita dapat melihat prasangka mengandung tipe afektif (berkaitann dengan perasaan negatif), kognitif (selalu berpikir tentang suatu stereotype) dan konasi (kecenderungan perilaku diskriminatif).

\section{b. Stareotipe}

Stareotipe merupakan salah satu bentuk utama prasangka antar etnik/ ras. Orang cenderung membuat kategori atas tampilan karakteristik perilaku orang lain berdasarkan kategori ras, jenis kelamin, kebangsaan dan tampilan komunikasi verbal maupun non-verbal. Stareotipe merupakan salah satu bentuk utama prasangka yang menunjukkan perbedaan "kami" (in group) yang selalu dikaitkan dengan superioritas kelompok in group dan yang cenderung mengevaluasi orang lain yang dipandang inferior yaitu "mereka" (out group). Menurut Verdeber (1986) dalam Liliwerii (2005: 207) menyatakan stareotipe adalah sikap dan juga karakter yang dimiliki seseorang dalam menilai karakteristik, sifat negative maupun positif orang lain, hanya berdasarkan keanggotaan orang itu pada kelompok tertentu. Sebagaimana halnya dengan sikap, stareotipe memiliki valensi dari positif hingga negative atas sesuatu yang disukai atau tidak.

Pemberian stareotipe merupakan gejala yang Nampak alami dalam proses hubungan antar rasa tau etnik sehingga tidak mungkin kita tidak melakukan stareotipe. Tajfel (1981) membedakan bentuk atau jenis stareotipe ini dalam stareotipe individu dan sosial. Stareotipe individu ialah generalisasi yang dilakukan individu dengan mengeneralisasikan karakteristik orang lain dengan ukuran yang luas dan jarak tertentu melalui proses kategori yang bersifat kognitif. Sedangkan stareotipe sosial terjadi ketika stareotipe itu telah menjadi evaluasi kelompok tertentu, telah menyebar dan meluas pada kelompok lain. Stareotipe ini berssifat unik dan berdasarkan pengalaman individu, namun kadang merupakan hasil pengalaman dan pergaulan dengan orang lain meupun dengan anggota kelompok kita sendiri.

\section{c. Etnosentrisme}

Etnosentrisme merupakan paham yang diperkenalkan oleh William Graham Summer 1960 (Sarlito Wirawan, 2002:30), seorang antropolog yang beraliran interaksionalisme. Summer berpandangan bahwa manusia pada dasarnya individualistis yang cenderung mementingkan diri sendiri, namun karena harus berhubungan dengan manusia lain, maka terbentuklah sifat hubungan yang antagonistik (pertentangan).

Berdasarkan keterangan diatas etnosentrisme adalah kecenderungan untuk menetapkan semua norma dan nilai budaya orang lain dengan standar budayanya sendiri. Etnosentrisme dapat mengakibatkan rasa prejudices (prasangka) dan penolakan secara otomatis terhadap ide-ide dari budaya lain dan dapat menimbulkan rasa takut bagi kelompok etnis lain maka 
terbentuklah sifat hubungan yang antagonistik (pertentangan). Supaya pertentangan itu dapat dicegah perlu ada falksway (adat kebiasaan) yang bersumber pada pola-pola tertentu. Mereka yang mempunyai falksway yang sama cenderung berkelompok dalam satu kelompok yang disebut etnis. Penjelasan diatas dapat disimpulkan bahwa seseorang tidak dapat mengatakan bahwa kultur yang mereka miliki adalah paling baik, paling humanis dan paling bermoral.

\section{d. Diskriminasi}

Unsur lain yang masih terkait dengan kultur adalah masalah diskriminasi. Diskriminasi mempunyai hubungan erat dengan relasi antar kelompok yang dominan dengan yang minoritas karena perlakuan yang tidak adil, biasanya sering berasal dari kelompok dominan terhadap kelompok minoritas (Ainul Yaqin, 2005: 21). Perlakuan tidak adil atau tindakan diskriminatif bisa terjadi dalam berbagai bidang kehidupan seperti ekonomi, politil, sosial, budaya, pendidikan, dan lain-lain. Perbedaan-perbedaan cultural seperti perbedaan agama, suku, ras, kelas sosial, gender, umur dan bahasa dapat dijadikan objek dan alas an untuk melakukan diskriminasi oleh kelompok dominan terhadap kelompok minoritas.

Sutarno (2007) menyatakan bahwa prasangka mencakup sikap dan keyakinan, maka diskriminasi mengarah pada tindakan. Tindakan diskriminasi biasanya dilakukan oleh orang yang memiliki prasangka kuat akibat tekanan tertentu, misalnya tekanan budaya, adat istiadat, kebiasaan atau hukum. Antara prasangka dan diskriminasi ada hubungan yang saling menguatkan, selama ada prasangka, disana ada diskriminasi.

\section{Implikasi Pembinaan Masyarakat Multikultural terhadap Kerukunan Antarumat \\ Beragama}

Seiring dinamika kehidupan yang terus berkembang dan semakin kompleksnya persoalan kerukunan maka fokus sekarang lebih memerlukan perwujudan rasa kemanusiaan dengan pembinaan masyarakat multikultural itu sendiri. Dalam kaitan pembinaan masyarakat multicultural pada segenap unsur dan lapisan masyarakat hasilnya kelak diharapkan terwujudnya masyarakat yang tidak saja mengakui perbedaan, tetapi mampu hidup saling menghargai dan menghormati secara tulus, komunikatif dan terbuka, tidak saling curiga, member tempat terhadap keragaman keyakinan, tradisi, adat maupun budaya dan paling utama adalah berkembang kerja sama sosial dan tolong menolong secara tulus sebagai perwujudan rasa kemanusiaan yang berasal dari ajaran agama masing-masing. (PKUB, Tim Depag, 2003)

Sehubungan dengan hal diatas, dan berdasarkan berbagai hasil kajian, bahwa para pemimpin agama dan etnik saat ini merasakan adanya keterbatasan komunikasi ini. Menurut 
Zainuddin Daulay (2005:10) "Bahwa masing-masing kelompok dan unsur masyarakat, tidak hanya pemuka agama dan pemuka masyarakat, perlu dilibatkan secara intensif dalam berbagai orientasi pembinaan masyarakat multikultural". Berdasarkan penjelasan diatas dapat dikatakan bahwa selain meningkatkan komunikasi kelompok-kelompok yang berbeda, juga sekaligus berguna sebagai upaya peningkatan pengelolaan kemajemukan masyarakat.

Perlunya pembinaan masyarakat multikultural, karena adanya perbedaan agama, budaya, suku, bahasa, adat istiadat dan kepentingan sosial lainnya. Karena kekayaan budaya dan kemajemukan yang dimiliki bangsa Indonesia , sesungguhnya bisa menjadi potensi integrasi, sebaliknya manakala perbedaan itu dikelola kurang baik, maka hal itu akan menjadi potensi disintegrasi bangsa.

\section{SIMPULAN}

Berdasarkan pembahasan diatas, dapat disimpulkan hal-hal sebagai berikut yaitu prinsipprinsip dasar multikultural adalah mengakui dan menghargai keberagaman kelompok masyarakat seperti etnik, ras, budaya, gender, strata sosial, agama, perbedaan kepentingan, keinginan, visi, keyakinan dan tradisi yang akan sangat membantu bagi terwujudnya perubahan perilaku yang kondusif dan sangat menjanjikan di tengah kehidupan masyarakat dan bangsa yang majemuk. Dengan demikian pendekatan multikultural tidak sesungguhnya berlandaskan pada kepemilikan yang mengisyaratkan pada memiliki atau dimiliki budaya tertentu tetapi berlandaskan pada kesadaran untuk menghargai dan menghormati.

Selain itu pula, pembinaan masyarakat multicultural yang dilakukan disini, jika dihubungkan dengan kondisi bangsa Indonesia saat ini kiranya menjadi sangat jelas bahwa multikulturalisme perlu dikembangkan di Indonesia. Dengan cara itu kita dapat memaknai "Bhinneka Tunggal Ika" secara tepat dan benar, seimbang dan proporsional. Melalui kebijakan ini pula kita dapat menerapkan "Persatuan Indonesia" dengan mengembangkan semangat nasionalisme sebagaimana diharapkan. Untuk itu penerapan dan pembinaan multikulturalisme di Indonesia perlu diberi cirri khusus dalam konteks untuk meningkatkan kerukunan antar umat beragama.

\section{DAFTAR PUSTAKA}

Aunurrahman, (2010). Pendidikan Karakter (Jurnal Publikasi Ilmiah Pendidikan Umum dan Nilai). Bandung : Asosiasi Sarjana dan Dosen Pendidikan Umum dan Nilai Indonesia.

Berry, John W, dkk. (1998). Psikologi Lintas Budaya. Jakarta : PT Gramedia Pustaka Utama. Budimasyah, Dasim, dkk. (2004). Dinamika Masyarakat Indonesia. Bandung : PT Ganesindo. 
Budimansyah, D. \& Suryadi, K. (2008). Pendidikan Kewarganegaraan dan Masyarakat Multikultural. Bandung : Program Studi Pendidikan Kewarganegaraan Sekolah Pasca Sarjana UPI.

Karliani, Eli. (2009). Pembinaan Masyarakat Multikultural Dalam Meningkatkan Integrasi Bangsa. Bandung : Tesis Magister pada Program Pasca Sarjana UPI (tidak diterbitkan).

Hemafitria. (2009). Pengembangan Wawasan Multikultural Dalam Mendiptakan Kerukunan Antar Umat Beragama. Bandung : Tesis Magister pada Program Pasca Sarjana UPI (tidak diterbitkan).

James T. Colins, dkk. (2005). Etnisitas di Kalimantan Barat. Pontianak : STAIN Pontianak Press

Koentjaraningrat. (1987). Manusia dan Kebudayaannya di Indonesia. Jakarta : Universitas Indonesia Press.

Kymlicka, Will. (2003). Kewarganegaraan Multikultural. Jakarta : PT Pustaka LP3ES.

Moerdiono. (1966). Makna Kerukunan Hidup Umat Beragama Menurut Tinjauan Paham Negara Ksatuan Republik Indonesia : Beberapa Pokok Pikiran . Jakarta : Sarasehan Sehari Majlis Ulama Indonesia.

Parekh, Bhikhu. (2007). "National Culture and Multiculturalism" dalam Kenneth Thomson (ed). Media and Cultural Regulation. London : Sage Publication.

Sapriya. (2002). Membangun Civil Society Tugas Pendidikan Kewaragnegaraan. Bandung : Civicus Edisi Juni.

Sugiyono. (2011). Metode Penelitian Kuantitatif, Kualitatif, dan R\&D. Bandung : Alfabeta.

Suparlan, P. (2005). Suku Bangsa dan Hubungan Antar Suku Bangsa. Jakarta : Yayasan Pengembangan Kajian Ilmu Kepolisian. 